\title{
RESEARCH OF THE NEW PRODUCT DEVELOPMENT PROCESS
}

\author{
Irena SILINEVICA ${ }^{1}$, Maris IGAVENS ${ }^{2}$, \\ Liene AMANTOVA-SALMANE ${ }^{3}$
}

\author{
${ }^{1}$ Dr.sc.ing., professor, Rezekne Academy of Technologies, Rezekne, Latvia, \\ e-mail: irena.silinevica@ru.lv, phone: +371 29103480 \\ 2Mg.soc.sc., scientific assistant, Rezekne Academy of Technologies, Rezekne, Latvia, \\ e-mail: maris.igavens@ru.lv, phone:+37129235941 \\ ${ }^{3} \mathrm{Mg}$. soc.sc., lecturer, Rezekne Academy of Technologies, Rezekne, Latvia, \\ e-mail: lienea@yahoo.com, phone: +37129429895
}

\begin{abstract}
New product development is the main factor of economic progress in building the economic competitive advantage. The life cycle of products becomes very short and it trends to be shorter year by year. It means that innovation becomes the main driver force

in the economy. The innovation level is not sufficient in Latvia. One of the most significant players in the innovation field are business incubators in Latvia. This research study underlines the role of evaluation of each stage of innovation processes. The authors offer a new model for the evaluation of innovation processes stage by stage. This model allows to identify the main problems that hinder innovation. This model allows to develop concrete proposals for improving the innovative climate in the country. The research is based on the authors' conducted research as a part of scientific grant of Rezekne Academy of Technologies "New product development process modeling and analysis in Latvia innovation barriers". The main methods, that are used in this research were as follows: content analysis, comparative analysis, synthesis, abstract and logical construction methods.
\end{abstract}

Keywords: innovation, methods, $R \& D$

JEL code: 0310,0320,C90

\section{Introduction}

New product development is the one of the key factors for progress and competitive advantage in each country. Companies across the world are faced with changes to both the production technology and service organization. The product life cycle has never been so short as now, therefore, new product development is one of the most important business tasks. Using only the traditional methods of increasing competitiveness, for example, cost reduction, it is not possible to remain on the market. Only a consistent approach and the development of creative ideas are the factors, which help a company to successfully operate. In any economy, a new product or service development are essential for economic growth and the welfare development vector. One of the possibilities for the 
development of new products in Latvia is the use of business incubators. Innovation development in Latvia is insufficient. This problem has not been established. There is the lack of sufficient quality methodology to investigate the causes of this problem.

The aim of the research study is to develop a model for the assessment of a new product development process.

To achieve this aim several tasks were defined:

- comparison different innovation measurement models;

- development a new model, which allows evaluating every stage of the innovation process;

The research subject: the innovation measurement models.

The hypothesis of this research is the following: It is possible to create innovation measurement model which allows to identify the main problems that hinder innovation.

In order to achieve this objective, the authors conducted theoretical studies, examining the existing innovation evaluation system, by using content analysis, deductive, logical and comparison and others methods. As a result, the authors worked out a new model for the assessment of innovation processes step by step.

\section{Research results}

Latvia has a low innovation performance - one of the EU-28, which is based on a small proportion of small innovative companies, investment in research and development (R \& D) activities and insufficient cooperation among science, technology and innovation development organisations, higher education and industry sectors. One of the most important public support measures in this area is the Latvian Investment and Development Agency (LIDA) operational programme "Entrepreneurship and Innovation" 2.3.2.1. activity "Business incubators" funded by the European Regional Development Fund (ERDF) (hereinafter - activity). These activities within the tenderers (start-up companies until 2 years of age) could receive business support services (advices and infrastructure support) and specialised services (new product development consultancy, design and prototyping services, laboratories, international marketing services, design services, etc.), by using appropriate agreements with the business incubator operators or / and the service providers. As part of the overall activity until 31 December 2013, the aid was received by 493 companies, prototype development and technological advice and services for new product development are among the most popular ones (Regionālo biznesa... 2014). 
The findings, related to the innovation process, approved -that traditional models of innovation management are directed to new product development that involves resource management, information and knowledge for the development of market demand (Clark, 1992). Product development is defined as the process of market information to create the final product for commercial purposes (Clark, Fujimato, 1991). Other authors defined the development of a new product as effective organisational and management processes by consuming minimum time and minimum cost to sell these products on a market (Wheelwright, Cklark, 1992). While Cooper (Cooper et. al., 2008), noted that new product development is a formal process with well-defined decision-making criteria. A set of activities that begins with the market research and ends with the production and sales of the product on the market (Ulrich, Eppinger, 2004). The new product development process consists of activities, which results in a new or redesigned product on the market. This process consists of creation opportunities, then selection from these opportunities and their implementation in a concrete product that is offered to consumers (Loch, Kavadias, 2008). Innovation process management is defined (What is..., 2016) as a systematic approach to nurturing the creative capabilities of employees and creating a workplace environment that encourages new ideas for workflows, methodologies, services or products. Scott Berkun (Scott Berkun, 2013) has defined 'innovation' as follows: 'Innovation is a significant positive change' by underlining that: 'It's a result. It's an outcome. It's something you work towards achieving on a project.' Different researchers use distinctive innovation measurement models, like the Diamond Model, the Funnel Model, the Innovation Value Chain Model, e.t.c. Dalia Gamal (Dalia Gamal, 2011) summarized different innovation measurement models and their respective focuses, and dimensions (see table 1).

The most applied model, which characterizes innovation, new products, and technological development processes, is a NASA model. This model is adopted by the European Space Agency and the European Commission with minor changes. This approach is also used for the main innovation policy instruments, for example, by implementing Horizont 2020, in innovation support competitions. This model foresees 10 stages of technology readiness levels. They are as follows (Technology readiness..., 2013):

TRL 0: idea;

TRL 1: basic research;

TRL 2: technology formulation;

TRL 3: applied research;

TRL 4: small scape prototype; 
TRL 5: large scale prototype;

TRL 6: prototype system;

TRL 7: demonstration system;

TRL 8: first of a kind commercial system;

TRL 9: full commercial application.

Table 1

Summarized comparison among different innovation measurement models (Source: Dalia Gamal, 2011)

\begin{tabular}{|c|c|c|c|}
\hline Model & Focus & Dimensions & Remarks \\
\hline $\begin{array}{l}\text { Diamond } \\
\text { Model }\end{array}$ & $\begin{array}{l}\text { Innovation process } \\
\text { Enabling factors } \\
\text { Linkage }\end{array}$ & $\begin{array}{l}\text { Strategy process } \\
\text { Organization } \\
\text { Linkage } \\
\text { Learning }\end{array}$ & $\begin{array}{l}\text { Adequate when the } \\
\text { innova -tion process } \\
\text { on its infan-cy. It } \\
\text { highlights key } \\
\text { dimensions of the } \\
\text { innovation process as } \\
\text { well as its enabling } \\
\text { institutional factor }\end{array}$ \\
\hline $\begin{array}{l}\text { Funnel } \\
\text { Model }\end{array}$ & $\begin{array}{l}\text { Technological } \\
\text { innovation } \\
\text { Product innovation } \\
\text { R\&D process as the } \\
\text { core activity }\end{array}$ & $\begin{array}{l}\text { Strategic thinking. } \\
\text { Portfolio management } \\
\text { \& metrics } \\
\text { Research } \\
\text { Ideation } \\
\text { Insight } \\
\text { Targeting } \\
\text { Innovation } \\
\text { development } \\
\text { Market development } \\
\text { Selling }\end{array}$ & $\begin{array}{l}\text { An adequate model } \\
\text { when } \\
\text { there is a due } \\
\text { innovation process in } \\
\text { the organization }\end{array}$ \\
\hline $\begin{array}{l}\text { Innovation } \\
\text { value } \\
\text { chain (IVC) }\end{array}$ & $\begin{array}{l}\text { Idea Management } \\
\text { Output performance }\end{array}$ & $\begin{array}{l}\text { Generation } \\
\text { Conversion Diffusion } \\
\text { knowledge acquisition } \\
\text { Building innovation } \\
\text { Commercializing } \\
\text { innovation }\end{array}$ & $\begin{array}{l}\text { It emphasizes the } \\
\text { assessment } \\
\text { of the output of the } \\
\text { innovation } \\
\text { process }\end{array}$ \\
\hline Oslo Manual & $\begin{array}{l}\text { Innovation } \\
\text { Linkage } \\
\text { Output in certain } \\
\text { duration }\end{array}$ & $\begin{array}{l}\text { Innovation } \\
\text { Linkage } \\
\text { Demand } \\
\text { Infrastructure } \\
\text { and institutional } \\
\text { framework Innovation } \\
\text { policies }\end{array}$ & $\begin{array}{l}\text { Very beneficial when } \\
\text { considering country } \\
\text { level } \\
\text { international } \\
\text { comparisons }\end{array}$ \\
\hline $\begin{array}{l}\text { Innovation } \\
\text { Radar }\end{array}$ & $\begin{array}{l}\text { Innovation output } \\
\text { performance }\end{array}$ & $\begin{array}{l}\text { Offerings } \\
\text { Customers Processes } \\
\text { Marketing }\end{array}$ & $\begin{array}{l}\text { It does not ensure the } \\
\text { sustainability of } \\
\text { innovation } \\
\text { process }\end{array}$ \\
\hline
\end{tabular}


However, this model is incomplete because it does not include factors, which characterise targeted interactions between a new product and a market. In other words, the successful commercialisation of innovations does not show in this model. This model just underlines the stages of the technology development processes. B.Hicks, S.Culley, A.Larsson, T.Larsson "A Methodology for Evaluating Technology Readiness during Product Development-", 2009, pointed to the shortcomings of this model and suggested the TRL model has to be supplemented with columns, which foreseen marketing and product implementation activities, see table 2 .

Table 2

Product readiness levels and the product development process

(source: Hicks, et.al, 2009)

\begin{tabular}{|c|c|c|c|c|c|}
\hline PRL & TRL & Marketing & Manufacturing & Other Functions & $\begin{array}{l}\text { Develop- ment } \\
\text { phase }\end{array}$ \\
\hline 1 & 2 & $\begin{array}{l}\text { Target market } \\
\text { identified. }\end{array}$ & - & $\begin{array}{l}\text { Business goals of } \\
\text { development } \\
\text { effort defined }\end{array}$ & Mission statement \\
\hline 2 & 3 & $\begin{array}{l}\text { Market seg-ments } \\
\text { defined. } \\
\text { Lead users\& their } \\
\text { needs identified. } \\
\text { Competing pro- } \\
\text { ducts analysed. }\end{array}$ & $\begin{array}{l}\text { Manufacturing } \\
\text { cost estimated } \\
\text { Production } \\
\text { feasibility assesed }\end{array}$ & $\begin{array}{l}\text { Single concept } \\
\text { selected for futher } \\
\text { development } \\
\text { Project justified } \\
\text { economically } \\
\text {-IPR issues } \\
\text { investigated }\end{array}$ & $\begin{array}{l}\text { Concept develop- } \\
\text { ment }\end{array}$ \\
\hline 3 & 4 & $\begin{array}{l}\text { Plan for product } \\
\text { options and } \\
\text { extended product } \\
\text { family formulated. }\end{array}$ & $\begin{array}{l}\text { Make-or-Buy } \\
\text { analysis } \\
\text { performed. } \\
\text { Key suppliers } \\
\text { identified. } \\
\text { Final assembly } \\
\text { scheme designed. }\end{array}$ & $\begin{array}{l}\text {-Support Make-or- } \\
\text { Buy analysis. } \\
\text {-Potential service } \\
\text { issues identified. }\end{array}$ & $\begin{array}{l}\text {-System-Level } \\
\text { Design }\end{array}$ \\
\hline 4 & 5 & $\begin{array}{l}\text { Marketing plan } \\
\text { developed }\end{array}$ & $\begin{array}{l}\text { Standard parts } \\
\text { identified. } \\
\text { Production pro- } \\
\text { cesses defined. } \\
\text { Tooling designed. } \\
\text { Long lead-time } \\
\text { tooling procured. } \\
\text { Quality assurance } \\
\text { processes defined. }\end{array}$ & $\begin{array}{l}\text {-Control } \\
\text { documentation } \\
\text { issued. }\end{array}$ & -Detal design \\
\hline
\end{tabular}


Table 2 continued

\begin{tabular}{|c|c|c|c|c|c|}
\hline 5 & \begin{tabular}{|l|}
6 \\
7 \\
8
\end{tabular} & $\begin{array}{l}\text { Promotion and } \\
\text { launch materials } \\
\text { developed. } \\
\text { Field testing } \\
\text { facilitated. }\end{array}$ & $\begin{array}{l}\text { Supplier 'ramp- } \\
\text { up'facilitated. } \\
\text { Fabrication and } \\
\text { assembly } \\
\text { processes refined } \\
\text { Commence work } \\
\text { force training } \\
\text { Quality assurance } \\
\text { processes refined. }\end{array}$ & $\begin{array}{l}\text {-Sales plan } \\
\text { finalised. } \\
\text {-Regulatory } \\
\text { approval/certifica } \\
\text { tion obtained. }\end{array}$ & $\begin{array}{l}\text { Testing and } \\
\text { refine-ment }\end{array}$ \\
\hline 8 & 9 & $\begin{array}{l}\text { Early 'production } \\
\text { ramp-up' products } \\
\text { placed with } \\
\text { preferred } \\
\text { customers. }\end{array}$ & $\begin{array}{l}\text { Work fource trai- } \\
\text { ning completed. } \\
\text { Operation of } \\
\text { entire production } \\
\text { system } \\
\text { commenced. }\end{array}$ & & $\begin{array}{l}\text { Production Rump- } \\
\text { Up }\end{array}$ \\
\hline 9 & 9 & $\begin{array}{l}\text { Product } \\
\text { promotion. }\end{array}$ & Full production & $\begin{array}{l}\text { Service \& support } \\
\text { infrastructure. }\end{array}$ & Product launch \\
\hline
\end{tabular}

Table 3

Model for research of innovation processes

(Source: own research)

\begin{tabular}{|l|l|l|l|}
\hline Nr. Stage & Actions & $\begin{array}{l}\text { Development } \\
\text { phase of } \\
\text { innovation }\end{array}$ \\
\hline 1 & Idea & $\begin{array}{l}\text { Basic research, Target market identified, Product } \\
\text { references and sketches develpment, Make-or-Buy } \\
\text { analysis performed, Market segments defined }\end{array}$ & $\begin{array}{l}\text { Product concept } \\
\text { defined }\end{array}$ \\
\hline 2 & Project & $\begin{array}{l}\text { Technology formulation, Key suppliers identified, } \\
\text { Product technical project, Product Competitevness } \\
\text { defined, Small scape prototype - alfa prototype }\end{array}$ & $\begin{array}{l}\text { Product detail } \\
\text { design } \\
\text { completed }\end{array}$ \\
\hline 3 & Prototyping & $\begin{array}{l}\text { Prototype validation in the real life environment - } \\
\text { beta prototype, Field testing facilitated. Standard } \\
\text { parts identified, Marketing plan developed, } \\
\text { Promotion and launch materials developed. }\end{array}$ & $\begin{array}{l}\text { Final patern of } \\
\text { product } \\
\text { demonstrated }\end{array}$ \\
\hline 4 & Production & $\begin{array}{l}\text { Supplier 'ramp- up' facilitated. } \\
\text { Fabrication and assembly processes refined } \\
\text { Tehnology, equipment and tools refined, } \\
\text { Promotion and launch materials developed. } \\
\text { Sales plan finalised. Regulatory approval/ } \\
\text { certification obtained. Product demonstration. } \\
\text { Sales with preferred customers. }\end{array}$ & $\begin{array}{l}\text { Product } \\
\text { production } \\
\text { demonstrated }\end{array}$ \\
\hline 5 & Sale & $\begin{array}{l}\text { Wperk force training completed. } \\
\text { commenced. Aftersales serive provided. } \\
\text { Advertisment. }\end{array}$ & $\begin{array}{l}\text { Service \& } \\
\text { support } \\
\text { developed }\end{array}$ \\
\hline
\end{tabular}


The examination of above mentioned models allowed to work out a new model for research of innovation processes. The authors offer the new model, divided into 5 stages (see Table 3 ).

Each stage is described taking into account the product design activities, the processes development activities, and the marketing activities. In addition, the phase of the innovation is determined in each stage.

The proposed model allows evaluating every stage of the innovation process, to identify the main problems that hinder innovation. This model allows developing concrete proposals for improving the innovative climate in the country. The next actions of the authors will draw attention to the practical research of innovation processes in firms, which are operated in the business incubators in Latvia, using the proposed model.

\section{Conclusions and suggestions}

New product development is the one of the key factors for progress and competitive advantage in each country. Latvia has a low innovation performance in comparison with other EU countries because of the lack of innovative companies, lack of investments in research and development, insufficient cooperation among science, higher education and industry sectors.

Different researchers use distinctive innovation measurement models, like the Diamond Model, the Funnel Model, the Innovation Value Chain Model, e.t.c. More applied model, which characterizes innovation, new products, and technological development processes, is a NASA model. This model is adopted by the European Space Agency and the European Commission with minor changes. The authors of this research study offer an important step in the solution to this problem - to perform an analysis of innovation processes stage by stage. The authors propose a new model, which allows evaluating every stage of the innovation process, to identify the main problems that hinder innovation. This model allows developing concrete proposals for improving the innovative climate in the country.

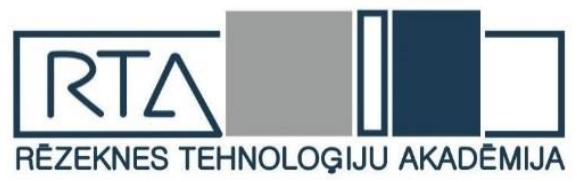

The research was elaborated with the financial assistance of Rezekne Academy of Technologies provided through a research grant for the "New product development process modeling and analysis in Latvia - innovation barriers". 


\section{References}

1. Biznesa inkubatori. Retrieved Mart 10,2016, from: http://www.rpr.gov.lv /uploads/filedir/ES_SF_ICmateriali/Seminara\%20programmas/Riga_2011-0421/LIAA_BI_21.04.2011.pdf

2. CLARK, K., FUJIMOTO,T. (1991). Product Development Performance:Strategy, Organization and Management in the World Auto Industry,Boston: Harvard Business School Press

3. COOPER, R.G. (2008). The Stage-Gates Idea-to-Launch Process-Update, What's New, and NexGen Systems. Journal of Product Innovation Management 25:213232.

4. DALIA, G. (2011). How to measure organizational innovativeness.Retrieved January 05, 2016, from: http://www.tiec.gov.eg/backend/Reports/Measuring OrganizationInnovativeness.pdf

5. EK Innovation Union Scoreboard 2015. Retrieved January 30, 2016, from: http://ec.europa.eu/growth/industry/innovation/facts-figures/scoreboards/ files/ius-2015_en.pdf

6. Latvijas nacionālā reformu programma "Eiropa 2020" stratēǵijas īstenošanai. Progresa ziṇojums 2014. Retrieved December 21, 2015, from: https://www.em .gov.lv/lv/eiropas_savieniba/strategija_eiropa_2020_/latvijas_nacionala_

7. LOCH, C., KAVADIAS, S. (2008). Handbook of New Product Development Management, Butterworth-Heinemann is an imprint of Elsevier.

8. LR Ekonomikas ministrijas "Regionālo biznesa inkubatori un radošo industriju inkubators sākotnējais izvērtējums. Retrieved Februar, 10, 2016 from: www.em.gov.lv

9. Technology readeness level. Retrieved December 10, 2015, from: http://ec.europa.eu/research/conferences/2013/energy_infoday/pdf/session_ 3_summary_of_the_calls_open_in_2014_-_philippe_schild.pdf.

10. The Best Definition of Innovation. Retrieved Retrieved December 10, 2015, from: http://scottberkun.com/2013/the-best-definition-of-innovation/

11. ULRICH K. T., EPPINGER S. D. (2004). 'Product Design and Development', 2nd edition, NY: McGraw Hill.

12. WHEELWRIGHT, S. CLARK.K. Creating Project Plans to Focus Product, Harvard Business Review, 1992.

13. What is innovation process management.Retrieved January 07, 2016, from: http://searchcio.techtarget.com/definition/innovation-process-managementIPM 


\title{
JAUNA PRODUKTA ATTİSTĪBAS PROCESA IZPĒTE
}

\section{Irēna SILINEVIČÁ, Māris IGAVENS² ${ }^{2}$, Liene AMANTOVA-SALMANE ${ }^{3}$}

\author{
${ }^{1}$ Dr.sc.ing., Rēzeknes Tehnologiju akadēmija, profesore \\ ${ }^{2}$ Mg.soc.sc., Rēzeknes Tehnoloǵiju akadēmija, zinātniskais asistents \\ ${ }^{3} \mathrm{Mg}$. soc.sc., Rēzeknes Tehnologiju akadēmija, lektore
}

\section{Kopsavilkums}

Jaunu produktu attīstība ir galvenais faktors ekonomikas konkurētspējas priekšrocības attīstībā. Produktu dzīves cikls gadu pēc gada arvien vairāk saīsinās. Tas nozīmē, ka inovācija kḷūst par galveno ekonomisko dzinējspēku. Latvijā ir zems inovatīvo sniegumu salīdzinājumā ar citām ES valstīm, jo trūkst inovatīvu uznēmumu, trūkst ieguldījumu pētniecībā un attīstībā, nepietiekama sadarbība starp augstākās izglìtības, zinātnes un rūpniecības nozarēs.

Šajā pētījumā uzsvērta inovāciju procesu izvērtēšanas nozīme jaunu produktu attīstības veicināšanā. Dažādi pētnieki izmanto atšksirīgu inovāciju novērtēšanas model̦us, kā 'Diamond', piltuves modeli, inovāciju 'Value Chain' modeli, utt. Pētījumā šie model̦i tiek salīdzināti. Vairāk piemērots modelis inovācijām, jauniem produktiem un tehnologijas attīstības procesiem ir NASA modelis, ko, ar nelielām izmaiṇām, izmanto Eiropas Kosmosa aǵentūras un Eiropas Komisija.

Autori piedāvā jaunu inovāciju procesa izvērtēšanas modeli soli pa solim. Šis modelis ḷauj identificēt galvenās problēmas, kas traucē jauninājumiem, kā arī izstrādāt konkrētus priekšlikumus, lai uzlabotu inovatīvu klimatu valstī.

Galvenās metodes, kas tiek izmantotas šajā izpētē ir: satura analīze, salīdzinošā analīze, sintēze, abstraktās un logiskās konstrukcijas metodes. Piedāvātajā rakstā tiek atspogul̦oti autoru veiktie pētījumi Rēzeknes Tehnologiju akadēmijā realizētajā zinātniskā granta „Jaunu produktu attīstības procesu modelēšana un analīze Latvijā inovācijas barjēras" ietvaros.

Atslēgas vārdi: inovācijas, metodes, P\&A. 